\title{
Anti-Xanthine Oxidase, Anti-Cholinesterase, and Anti-Inflammatory Activities of Fruiting Bodies of Phellinus gilvus
}

Ki Nam Yoon, Hyung Seok Jang

Department of Clinical Laboratory Science, Ansan University, Ansan, Korea

\section{마른진흙버섯 자실체의 Xanthine Oxidase, Cholinesterase 및 염증 저해 효과}

윤기남, 장형석

안산대학교 임상병리과

\begin{abstract}
Phellinus gilvus is a medicinal mushroom used that has been used in folk medicine in Asian countries for centuries. The aim of this study was to investigate the anti-xanthine oxidase, anti-cholinesterase, and anti-inflammatory activities of methanol (ME) and hot water (HW) extracts prepared from fruiting bodies of Ph. gilvus. ME and HW had good anti-xanthine oxidase (XO) activities compared to allopurinol, an inhibitor of xanthine oxidase. ME showed comparable and slightly lower inhibitory activity against acetylcholinesterase (AChE) and butyrylcholinesterase (BChE), respectively, than galanthamine, a standard $\mathrm{AChE}$ and $\mathrm{BChE}$ inhibitor. ME also showed a protective effect against glutamate-induced cytotoxicity at $40 \mathrm{mg} / \mathrm{mL}$ and $100 \mathrm{mg} / \mathrm{mL}$ in PC-12 cells. ME $(0.5 \sim 2.0 \mathrm{mg} / \mathrm{mL})$ significantly inhibited nitric oxide (NO) production in RAW 264.7 murine macrophage cells stimulated with lipopolysaccharide (LPS). Carrageenan-induced hind-paw edema in rats was significantly reduced $2 \sim 6 \mathrm{hr}$ after treatment with $50 \mathrm{mg} / \mathrm{kg}$ of ME, which was comparable to administration of $5 \mathrm{mg} / \mathrm{kg}$ of indomethacin, the positive control. These results demonstrate that $\mathrm{ME}$ and $\mathrm{HW}$ of Ph. gilvus fruiting bodies possess good anti-xanthine oxidase, anti-cholinesterase, and anti-inflammatory activities.
\end{abstract}

Key words: Anti-inflammation, Anti-xanthine oxidase, Cholinesterase inhibitors, Phellinus gilvus

This is an Open Access article distributed under the terms of the Creative Commons Attribution Non-Commercial License (http://creativecommons.org/licenses/by-nc/4.0) which permits unrestricted non-commercial use, distribution, and reproduction in any medium, provided the original work is properly cited.

Copyright (C) 2018 The Korean Society for Clinical Laboratory Science. All rights reserved.
Corresponding author: Ki Nam Yoon Department of Clinical Laboratory Science, Ansan University, 155 Ansandaehak-ro, Sangnok-gu, Ansan 15328, Korea Tel: 82-31-400-7068 Fax: 82-31-363-7702 E-mail: kinam@ansan.ac.kr

Received: May 19, 2018 Revised $1^{\text {st: }}$ July 30, 2018 Revised 2 ${ }^{\text {nd }}$ : August 9, 2018 Revised 3 ${ }^{\text {rd }}$ : August 16, 2018 Accepted: August 16, 2018

\section{서 론}

의식주 환경의 개선과 의학의 발달로 인한 인간의 수명 연장 으로 노령인구가 증가하면서 노인성 치매가 증가하는 경향을 나타내고 있으며 65 세 이상의 노인 인구 중 약 $10 \%$ 가 치매 발병 률을 보이고 있어 경제적, 사회적으로 큰 문제를 야기하고 있다[1]. 노인성치매는 크게 뇌혈관성 치매와 알츠하이머병(Alzheimer disease, $\mathrm{AD}$ )으로 나누어지는데 이중 알츠하이머병이 치매의 $50 \%$ 이상을 차지하고 있다. $\mathrm{AD}$ 의 원인으로는 뇌 속의 콜린 (choline)성 신경계의 변화, 과도한 glutamate와 amyloid plaque 생성, tau 단백질의 침착, 염증 등이 주요 인자로 알려져 있다[2]. 알츠하이머병 증상의 하나인 기억력 감퇴 현상은 뇌의 신경전달물질인 아세틸콜린 함량의 감소와 깊이 관련되어 있다 는 연구결과가 널리 보고되고 있다[3]. Talesa [4]는 뇌 속에 
acetylcholine (ACh)을 가수분해하는 acetylcholinesterase (AChE) 효소의 농도가 증가하면 신경세포 내의 콜린성 신경전 달물질이 감소하여 기억 및 인지 기능에 장애가 일어난다고 보 고하였다. Block 등[5]은 신경 전달물질의 하나인 glutamate는 신경의 정상적인 반응을 일으키는 물질이지만, 뇌 속의 농도가 정상 이상으로 과도하게 높아지면 뇌세포 내의 활성산소의 양 을 증가시키고 유입되는 칼슘의 양을 증가시킴으로써 독성을 유발해 뇌세포에 치명적인 손상을 일으킨다고 보고하였다. 최 근 치매의 치료에 사용되고 있는 의약품이 오심, 구토, 체중 감 소, 수면장애, 간 독성, 위궤양, 천식 등의 부작용을 일으키는 임 상 사례가 보고되면서 기존의 의약품을 대체해야 할 필요성이 대두되어 새로운 천연물을 이용한 치매의 치료제를 개발하려는 연구가 시도되고 있다[6].

염증반응은 외부의 물리적, 화학적 자극 또는 세균이나 바이 러스 등의 감염에 대응해 체내의 면역세포가 이를 인지하고 염 증 매개 물질을 분비하여 손상된 조직을 복구하고 재생하려는 방어 작용이다[7]. 대식세포(macrophages)는 염증반응에 관 여하는 대표적인 면역세포로써 lipopolysaccharid (LPS)와 같 은 유발물질에 의해 활성화되면 활성화된 대식세포에서 분비하 는 각종의 염증 물질은 염증반응을 촉진하는 여러 인자들과 상 승효과를 일으켜 기관지 천식, 기관지염, 류머티즘 관절염, 심혈 관계 질환, 치매 등 만성 만성질환의 원인이 되고 있다[8, 9]. 염 증반응에 사용되는 제제는 염증으로 인해 유발되는 만성질환을 예방하거나 제어하는 것을 주목적으로 하고 있다[10]. 현재 사 용되는 대부분의 항염증제제를 장기간 복용한 경우 출혈성 소 화관 궤양, 신장의 기능저하, 혈압 상승, 혈전 형성 등 소화기나 순환계에 질환을 유발하는 등의 임상 사례가 보고되고 있다 [11]. 따라서 염증을 억제하고 염증 매개체들의 생성을 보다 효 과적으로 저해할 수 있는 천연 재료를 이용한 새로운 항염증제 의 개발이 큰 주목을 받고 있다.

대부분의 버섯은 담자균문(Basiomycota)에 속해있고 일부 의 버섯이 자낭균문(Ascomycota)에 속해있다. 최근 기능성 건 강식품에 대한 관심이 높아지면서 버섯에 대한 소비도 증가하 고 있다. 고등균류에 속하는 버섯은 예로부터 식용과 약용으로 널리 이용되어 왔으며 당뇨, 비만, 암, 고혈압, 고지혈증 등의 성 인병을 예방하고 개선하는 효과가 밝혀짐에 따라 버섯의 생리 활성 증진에 대한 연구가 널리 진행되고 있다[12-14]. 마른진훍 버섯은 담자균문의 소나무비늘버섯목(Hymenochaetales), 소 나무버섯과(Hymenochaetaceae), 진흙버섯속(Phellinus)에 속하는 약용버섯으로 한국을 비롯한 중국, 일본에서 오래전부 터 “상황” 으로 불리며 주로 암의 치료에 이용해 왔으나 최근 항
산화, 항균, 고지혈증 및 폐렴 등의 약용 효과에 대한 선행연구 가 수행된 바 있다[15-17]. 이에 본 연구에서는 최근 인공 재배 에 성공하여 시장에서 판매되는 마른진휽버섯의 자실체를 구입 하여 메탄올과 열수로 추출한 물질의 xanthine oxidase, cholinesterase 및 염증의 저해작용에 대한 연구를 수행하였다.

\section{재료 및 방법}

\section{1. 실험재료}

실험에 사용한 마른진휽버섯의 자실체는 서울의 경동 한약 재 시장에서 구입하여 $45^{\circ} \mathrm{C}$ 의 열풍건조기에서 48 시간 건조하 고 마쇄 후 $-70^{\circ} \mathrm{C}$ 의 저온 냉동고에 보관하면서 실험에 사용하 였다.

\section{2. 성분의 추출}

Shim 등[18]의 방법에 따라 건조한 마른진흙버섯 자실체의 분말에 $80 \%$ 메탄올과 열수를 이용해 성분을 추출하여 실험에 사용하였다. 즉, $50 \mathrm{~g}$ 의 마른진흙버섯 자실체의 분말을 $80 \%$ 의 메탄올 용액(Duksan, Ansan. Korea) 1,000 mL에 침지하여 48 시간 동안 상온에서 3회 추출한 후 이 추출액을 모아 여과지 (Avantec Roshi, Tokyo, Japan)로 여과한 후 $40^{\circ} \mathrm{C}$ 에서 회전 감 압농축기(N-1000, EYELA, Tokyo, Japan)을 이용하여 감압 농 축하고 농축액 내의 수분은 동결건조기(FDU-8612, Operon, Kimpo, Korea)로 제거하여 메탄올 추출물의 분말을 얻었다. 열수추출물은 3 차 증류수 $1,000 \mathrm{~mL}$ 에 $50 \mathrm{~g}$ 의 자실체 분말을 넣 어 $100^{\circ} \mathrm{C}$ 에서 10 시간 동안 추출하였다. 추출 후 추출액은 $4^{\circ} \mathrm{C}$ 에서 24시간 동안 정치시킨 후 여과지(Avantec Roshi, Tokyo, Japan)로 여과하고 동결건조기로 여과액의 수분을 제거하여 열 수추출물 분말을 얻었다.

\section{3. 총 폴리페놀 및 플라보노이드 함량}

총 폴리페놀 함량은 Folin-Denis 법을 변형한 Swain 등[19] 의 방법에 따라 측정하였다. 즉, 마른진휽버섯 메탄올과 열수추 출물을 각각 $1 \mathrm{mg} / \mathrm{mL}$ 농도로 메탄올에 녹인 후 FolinCiocalteau's phenol reagent와 $10 \%$ 의 $\mathrm{Na}_{2} \mathrm{CO}_{3}$ 용액을 각각 1 $\mathrm{mL}$ 씩 차례로 가한 후 실온에서 60분간 반응시킨 후 UV/VIS Spectrophotometer (Optizen POP, CM Science, Busan, Korea)를 이용해 $700 \mathrm{~nm}$ 에서 흡광도를 측정하였다. 총 폴리페 놀의 측정은 표준물질로 gallic acid (Sigma-Aldrich, St. Louis, $\mathrm{USA}$ 를 0 100 mg/mL의 농도로 제조한 후 시료와 동일한 방 법으로 처리하여 검량선을 작성한 후 추출물의 총 폴리페놀 함 
량을 구하였다.

총 플라보노이드 함량의 측정은 Moreno 등[20]의 방법에 따 라 $1 \mathrm{mg} / \mathrm{mL}$ 농도의 시료액에 $10 \%$ aluminum nitrate $0.1 \mathrm{~mL}$, $1 \mathrm{M}$ potassium acetate $0.1 \mathrm{~mL}$ 및 ethanol $4.3 \mathrm{~mL}$ 를 차례로 가하고 혼합한 후 실온에서 40 분간 방치 후 UV/VIS Spectrophotometer (Optizen POP, CM Science, Busan, Korea)를 이용해 $415 \mathrm{~nm}$ 에서 흡광도를 측정하였다. 총 플라보노이드 함 량은 quercetin (Sigma-Aldrich, St. Louis, USA)을 표준물질 로 하여 얻은 검량선을 이용하여 각각의 추출물의 총 플라보노 이드 함량을 구하였다.

\section{4. 세포배양}

실험에 사용한 RAW 264.7과 PC-12 세포주는 한국세포주 은행(Korean Cell Line Bank, KCLB)에서 분양받았으며 이들 세포의 배양에는 각각 Dulbecco's Modified Eagle's Medium (DMEM, Gibco, NY, USA)와 Roswell Park Memorial Institute Medium (RPMI-1640, Gibco, NY, USA) 배지를 기 본배지로 하고 이 배지에 $10 \%(\mathrm{v} / \mathrm{v})$ fetal bovine serum (FBS), $100 \mathrm{U} / \mathrm{mL}$ penicillin 및 $100 \mathrm{mg} / \mathrm{mL}$ streptomycin을 첨가하 여 $37^{\circ} \mathrm{C}, 5 \% \mathrm{CO}_{2}$ 의 조건으로 배양하여 실험에 사용하였다.

\section{RAW 264.7 세포 독성}

마른진휽버섯 자실체의 메탄올과 열수 추출물의 RAW 264.7 세포에 대한 독성은 Mosmann의 방법[21]에 따라 수행하였다. 지수기에 도달한 세포주를 DMEM 배지가 분주된 96-well plate에 $2 \times 10^{5} \mathrm{cell} / \mathrm{mL}$ 의 농도로 분주하고 24 시간 배양한 후, 배지의 상층 액을 제거하고 마른진휽버섯 추출물을 10,100 , $500,1,000,2,000 \mathrm{mg} / \mathrm{mL}$ 농도로 $200 \mathrm{~mL}$ 씩 새 배지에 첨가하 여 48시간 추가 배양하였다. 배양 완료 후 상층액을 제거하고 각 각의 well에 MTT용액(5 mg/mL in PBS) $10 \mathrm{~mL}$ 를 첨가한 후 $37^{\circ} \mathrm{C}, 5 \% \mathrm{CO}_{2}$ 배양기에서 4 시간 동안 배양하여 $\mathrm{MTT}$ 를 환원 시켰다. MTT의 환원에 의해 생성된 자주색 formazan의 결정 은 $150 \mathrm{~mL}$ 의 $\mathrm{DMSO}$ 로 녹인 다음 microplate reader (SpectraMax 340PC, California, USA)를 이용하여 $540 \mathrm{~nm}$ 에 서 흡광도를 측정하였다.

\section{Xanthine oxidase $(\mathrm{XO})$ 저해 활성}

Xanthine oxidase 효소의 저해활성 실험은 Stirpe와 Corte Della의 방법[22]에 따라 수행하였다. 농도가 다른 추출물 $(0.5$ $8.0 \mathrm{mg} / \mathrm{mL}$ ) $0.1 \mathrm{~mL}$ 와 $0.1 \mathrm{M}$ potassium phosphate buffer (pH 7.5) $0.6 \mathrm{~mL}$ 에 $2 \mathrm{mM}$ 의 xanthine 기질액 $0.2 \mathrm{~mL}$ 를 첨가하
고 xanthine oxidase (0.2 uint $/ \mathrm{mL}) 0.1 \mathrm{~mL}$ 를 가한 다음 $37^{\circ} \mathrm{C}$ 에서 15 분간 반응시킨 후 $1 \mathrm{~N} \mathrm{HCl} 1 \mathrm{~mL}$ 를 가하여 반응을 중지 시킨 후, UV-VIS spectrophotometer (Optizen POP, CM Science, Busan, Korea)를 이용해 $290 \mathrm{~nm}$ 에서 흡광도를 측정 해 반응액 중에 생성된 uric acid의 양을 구하였다. 양성대조군 으로 통증 치료에 이용되는 xanthine oxidase 저해제인 allopurinol을 사용하였다. Xanthine oxidase 저해활성(\%)은 다음의 식에 의하여 산출하였다.

Inhibition effect $(\%)=[1-(\mathrm{A}-\mathrm{B}) / \mathrm{C})] \times 100$

$\mathrm{A}$ : Xanthine 용액 ( $2 \mathrm{mM})$ 에 추출물 시료와 효소액을 첨가하 여 반응시킨 후의 흡광도

$\mathrm{B}: \mathrm{A}$ 에서 효소액 대신 증류수 $0.1 \mathrm{~mL}$ 를 첨가하여 반응시킨 후의 흡광도

$\mathrm{C}: \mathrm{A}$ 에서 추출물 시료 대신 증류수 $0.1 \mathrm{~mL}$ 를 첨가하여 반응 시킨 후의 흡광도

\section{Acetylcholinesterase (AChE) 저해 활성}

$\mathrm{AChE}$ 의 효소의 저해 활성은 Ellman 등[23]의 방법에 따라 acetylthiocholine iodide를 기질로 사용하였으며 $\mathrm{AChE}$ 에 의 해 생성되는 thiocholine을 DTNB와 반응시켜 생성된 2-nitrobenzoi-5-mercatothocholine과 5-thio-2-nitrobenzoate 의 흡광도를 측정하였다. 즉, 96 well microplate에 $100 \mathrm{~mL}$ 의 AChE assay buffer (0.1 M Tris-HCl, pH 8.2), $10 \mathrm{~mL}$ 의 0.5 $\mathrm{U} / \mathrm{mL}$ AChE (dissolved in assay buffer containing 10\% glycerol) 및 $0.063 \sim 1.0 \mathrm{mg} / \mathrm{mL}$ 의 농도로 희석한 $10 \mathrm{~mL}$ 의 시 료를 가하고 상온에서 10 분 동안 진탕배양 후 $10 \mathrm{~mL}$ 의 $10 \mathrm{mM}$ DTNB와 $100 \mathrm{mM}$ acetylthiocholine $5 \mathrm{~mL}$ 을 가해 2분 동안 반 응시킨 후 microplate reader (SpectraMax 340PC, California, $\mathrm{USA}$ )를 이용하여 $405 \mathrm{~nm}$ 에서 흡광도를 측정하였다. 이때 효소 대신 동량의 assay buffer를 가한 것을 control로 galanthamine 을 가한 것을 양성대조군으로 사용하였으며, $\mathrm{AChE}$ 의 저해활성 은 다음의 수식을 이용하여 구하였다.

$$
\begin{aligned}
& \mathrm{AChE} \text { 저해율 }(\%)=\left[100-\left(\left(\mathrm{A}_{\text {sample }} / \mathrm{A}_{\text {control }}\right)\right] \times 100\right. \\
& \text { 이때, } \mathrm{A}_{\text {control }} \text { 은 대조군의 흡광도, } \mathrm{A}_{\text {sample }} \text { 은 시료군의 흡광도이다. }
\end{aligned}
$$

\section{Butyrylcholinesterase (BChE) 저해 활성}

$\mathrm{BChE}$ 의 효소활성은 Ellman 등[23]의 방법에 따라 butyrylcholine iodide를 기질로 사용하였으며 $\mathrm{BChE}$ 의 가수 분해로 생성된 thiocholine을 DTNB와 반응시켜 그 결과 생성 
되는 반응물을 $405 \mathrm{~nm}$ 에서 흡광도를 측정하였다. 즉, 96 well microplate에 $100 \mathrm{~mL}$ 의 BChE assay buffer (0.1 M Tris-HCl, $\mathrm{pH}$ 8.2), $10 \mathrm{~mL}$ 의 $0.5 \mathrm{U} / \mathrm{ml} \mathrm{BChE}$ (dissolved in assay buffer containing $10 \%$ glycerol) 및 $0.063 \sim 1.0 \mathrm{mg} / \mathrm{mL}$ 의 농도로 희 석된 $10 \mathrm{~mL}$ 의 시료를 가하고 상온에서 10 분 동안 진탕배양 후 $10 \mathrm{~mL}$ 의 $10 \mathrm{mM} \mathrm{DTNB}$ 와 $100 \mathrm{mM}$ acetylthiocholine $5 \mathrm{~mL}$ 를 가해 2분 동안 반응시킨 후 microplate reader (SpectraMax 340PC, California, USA)를 이용하여 $405 \mathrm{~nm}$ 에서 흡광도를 측정하였다. 이 때 효소 대신 동량의 assay buffer를 가한 것을 control로 galanthamine를 가한 것을 양성대조군으로 사용하 였으며, $\mathrm{BChE}$ 의 저해활성은 다음의 수식을 이용하여 구하였다.

$\mathrm{BChE}$ 저해율 $(\%)=\left[100-\left(\left(\mathrm{A}_{\text {sample }} / \mathrm{A}_{\text {control }}\right)\right] \times 100\right.$

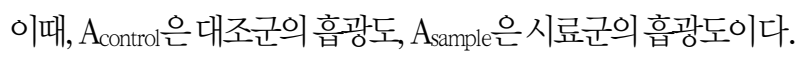

\section{Glutamate 독성에 의해 유도된 세포사멸의 억제 효과}

본 실험에는 쥐의 크롬친화세포종(rat pheochromocytoma) 에서 유래한 PC-12 세포를 사용하였다. 이 세포에 신경 성장인 자(nerve growth factor, NGF)를 처리하면 신경세포로 최종 분화하는 특성으로 인해 신경 분화의 연구모델로 널리 사용되 고 있다[24]. Glutamate에 의해 PC-12 세포에 유도된 독성이 마른진흙버섯 자실체의 메탄올과 열수추출물에 의해 억제되는 실험은 $\mathrm{Ma}$ 등[25]의 방법을 변형하여 수행하였다. $10 \%$ 의 $\mathrm{FBS}$ 가 첨가된 RPMI- 1640 배지에 PC-12 세포를 $5 \% \mathrm{CO}_{2}$ 와 $37^{\circ} \mathrm{C}$ 의 조건에서 3 일 배양한 후, 96-well plate에 $1 \times 10^{5}$ cells/well 농도로 분주하여 24 시간 배양한 다음, glutamate가 $10 \mathrm{mM}$ 농 도로 함유된 배지에 옮겨 12시간 배양하여 독성을 유도한 뒤 마 른진휽버섯의 메탄올과 열수 추출물이 각각 $5,10,20,40,100$ $\mathrm{mg} / \mathrm{mL}$ 농도로 첨가된 배지에서 24 시간 배양하였다. 배양 후 배지를 제거하고 $100 \mathrm{~mL}$ 의 $\mathrm{DMSO}$ 를 처리하여 MTT를 용해한 후 microplate reader로 $570 \mathrm{~nm}$ 의 흡광도에서 측정해 세포의 생존율을 구하였다.

\section{Nitric oxide (NO) 생성 저해 효과}

마른진흙버섯의 메탄올과 열수추출물에 의한 $\mathrm{NO}$ 의 생성 저 해효과는 Ryu 등[26]의 방법을 이용하여 측정하였다. DMEM 배지가 들어있는 96 well plate에 RAW 264.7 세포를 $5 \times 10^{4}$ cell/well로 분주하여 12시간 배양 후 마른진휽버섯 추출물을 $0,0.5,1.0$ 및 $2.0 \mathrm{mg} / \mathrm{mL}$ 의 농도로 처리하고 1 시간 경과 후 $\mathrm{LPS}$ 를 $1 \mu \mathrm{g} / \mathrm{mL}$ 농도로 첨가하여 24시간 동안 배양하였다. 배 양 후 상층액 $100 \mu \mathrm{L}$ 를 취한 후 동량의 Griess reagent
(Sigma-Aldrich Co., St. Louis, USA) $100 \mu \mathrm{L}$ 를 넣어 총량이 $200 \mu \mathrm{L}$ 되도록 하고 상온에서 10 분간 반응시킨 후 생성된 NO 의 양을 microplate reader를 이용하여 $540 \mathrm{~nm}$ 에서 흡광도를 측정하였다. $\mathrm{NO}$ 의 농도는 아질산염 $\left(\mathrm{NaNO}_{2}\right)$ 의 농도별 표준곡 선을 이용하여 구하였다.

\section{Carrageenan에 의한 부종유발 및 항염증 효과}

흰쥐의 뒷발 바닥에 급성 부종을 유발하는 실험은 Winter 등 [27]의 방법에 따라 수행하였다. 생리식염수에 녹인 $0,5,15$, $50 \mathrm{mg} / \mathrm{kg}$ 농도의 마른진흙버섯 추출물과 $0.5 \mathrm{mg} / \mathrm{kg}$ 농도의 indomethacin을 마리당 각각 $0.1 \mathrm{~mL}$ 씩 오른쪽 뒷발바닥에 주 사하고 30 분이 경과한 후 $1 \%$ 의 carrageenan 용액을 흰쥐의 뒷 발 바닥에 $0.1 \mathrm{~mL}$ 씩 주사하였다. 본 실험에는 처리 군 당 각각 5 마리의 흰쥐를 사용하였다. 항염증 효과는 각각의 마른진휽버 섯 메탄올 추출물과 indomethacin을 주사하고 carrageenan 을 추가로 투여해 흰쥐의 뒷발 바닥에 생긴 부종의 용적을 plethysmometer (MK-101P, Tokyo, Japan)로 측정하여 구하 였다. 흰쥐의 뒷발 바닥에 기염제인 carrageenan을 주입하기 전을 0 으로 하고 주입 후 $2,4,6$ 시간이 지난 후 부종에 의해 증가 한 뒷발의 용적을 각각의 실험 군 별로 측정하여 다음의 식에 의 하여 부종의 증가율을 산출하였다.

부종증가율 $(\%)=\left(\mathrm{V}_{\mathrm{t}}-\mathrm{V}_{\mathrm{n}}\right) / \mathrm{V}_{\mathrm{n}} \times 100$

$\mathrm{V}_{\mathrm{t}}=$ 주입 후 일정 시간 후의 뒷발의 용적

$\mathrm{V}_{\mathrm{n}}$ =주입 직후 뒷발의 용적

\section{2. 통계 처리}

실험은 3회 이상 반복 실험을 통하여 얻은 각각의 결과를 mean \pm S.D로 나타내었다. 각 시료 농도 군에 대한 통계적 유의 검정은 대조군과 비교하여 Student's t-test (SPSS PASW Statistics 18.0, SPSS Inc., Chicago, IL, USA) 후, $P<0.05$ 수준 에서 통계적으로 유의성 있는 결과로 표시하였다.

\section{결 과}

\section{1. 총 폴리페놀 및 플라보노이드 함량}

마른진흙버섯 자실체의 메탄올과 열수 추출물의 총 폴리페 놀 및 플라보노이드 함량의 결과를 잘 정리한 후(Table 1) 나타 냈다. 메탄올 추출물의 총 폴리페놀 함량과 총 플라보노이드 함 량을 3번에 걸쳐 측정한 결과 각각 $31.37 \pm 1.69 \mathrm{mg} / \mathrm{g}$ 과 $6.17 \pm 0.57 \mathrm{mg} / \mathrm{g}$ 으로 나타났고, 열수 추출물의 총 폴리페놀과 
Table 1. Total phenolic and flavonoids content of methanol and hot water extracts from fruiting bodies of Phellinus gilvus

\begin{tabular}{cccc}
\hline Samples & $\begin{array}{c}\text { Extraction } \\
\text { yield \%(w/w) }\end{array}$ & $\begin{array}{c}\text { Phenolic } \\
\text { content }(\mathrm{mg} \\
\text { GAEs/g extract) }\end{array}$ & $\begin{array}{c}\text { Flavonoids } \\
\text { content }(\mathrm{mg} \\
\text { QEs/g extract) }\end{array}$ \\
\hline $\begin{array}{c}\text { Methanol } \\
\text { extract }(\mathrm{N}=3)\end{array}$ & 10.3 & $31.37 \pm 1.69$ & $6.17 \pm 0.57$ \\
$\begin{array}{c}\text { Hot water } \\
\text { extract }(\mathrm{N}=3)\end{array}$ & 6.2 & $20.27 \pm 1.27$ & $17.33 \pm 0.85$ \\
\hline
\end{tabular}

The values are means $\pm S D(N=3)$.

Abbreviations: GAEs, gallic acid equivalents; QEs, quercetin equivalents.

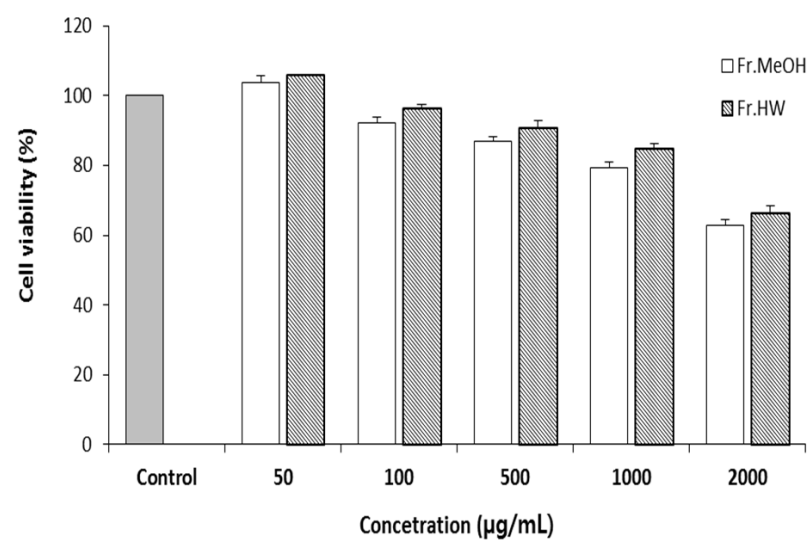

Figure 1. In vitro cytotoxicity against RAW 264.7 cells at different concentrations of methanol and hot water extracts from fruiting bodies of Phellinus gilvus. The values are means $\pm \mathrm{SD}(\mathrm{N}=3)$. Abbreviation: Fr.MeOH, fraction extracted with $80 \%$ methanol; Fr.HW, fraction extracted with hot water.

플라보노이드 함량은 각각 $20.27 \pm 1.27 \mathrm{mg} / \mathrm{g}$ 과 $17.33 \pm 0.85$ $\mathrm{mg} / \mathrm{g}$ 으로 나타났다. 따라서 메탄올 추출물은 열수 추출물에 비 해 총 폴리페놀의 함량이 약 1.54 배 높았으나 총 플라보노이드 의 함량은 열수 추출물이 메탄올 추출물에 비해 약 2.89 배 높았 다.

\section{RAW 264.7 세포 독성}

마른진흙버섯 자실체의 메탄올과 열수 추출물이 쥐의 대식 세포인 RAW 264.7 세포의 생존율에 미치는 효과를 규명하기 위해 메탄올과 열수 추출물을 $50,100,500,1,000,2,000$ $\mu \mathrm{g} / \mathrm{mL}$ 의 농도로 RAW 264.7 세포에 처리하고 MTT 방법을 이 용하여 세포의 생존율을 조사하였다. 실험결과 RAW 264.7 세 포는 $50 \sim 2,000 \mathrm{mg} / \mathrm{mL}$ 의 메탄올 추출물 농도에서 103.50 62.63\%의 생존율을 보였고, 동일한 농도의 열수 추출물은 $105.57 \sim 66.17 \%$ 의 생존율을 보였다(Figure 1). 따라서 메탄올 과 열수 추출물 $50 \mathrm{mg} / \mathrm{mL}$ 의 농도에서 RAW 264.7 세포의 생존 율이 모두 $100 \%$ 이상으로 나타나서 이들 농도의 추출물은

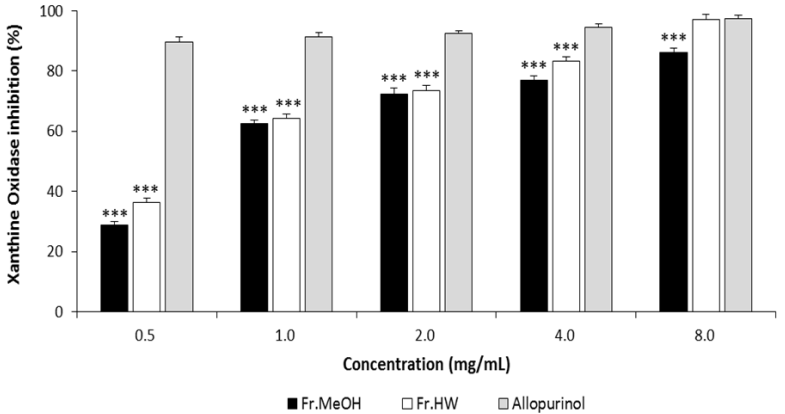

Figure 2. Xanthine oxidase inhibitory activity of methanol and hot water extract from fruiting bodies of Phellinus gilvus. The values are means $\pm \mathrm{SD}(\mathrm{N}=3)$. ${ }^{\star \star \star} P \leq 0.001$ vs. allopurinol group. Abbreviation: Fr.MeOH, fraction extracted with $80 \%$ methanol; Fr.HW, fraction extracted with hot water.

RAW 264.7 세포의 증식을 촉진하는 효과를 보였으나 2,000 $\mathrm{mg} / \mathrm{mL}$ 농도에서 RAW 264.7 세포의 생존율은 각각 $62.63 \%$ 와 66.17\%로 나타내 추출물의 농도가 증가함에 따라 RAW 264.7 세포의 생존율은 각각 농도 의존적으로 감소하였다. 따라서 마 른진흙버섯 자실체 추출물을 이용한 RAW 264.7 세포의 nitric oxide (NO) 생성 저해 실험에서는 추출물 농도 50 2,000 범 위에서 수행하였다.

\section{Xanthine oxidase $(\mathrm{XO})$ 저해 활성}

$\mathrm{XO}$ 효소에 대한 마른진휽버섯 자실체의 메탄올과 열수추출 물의 저해활성 실험 결과를 Figure 2에 표시하였다. 메탄올과 열수추출물의 농도 $0.5 \sim 8.0 \mathrm{mg} / \mathrm{mL}$ 범위 내에서 XO에 대한 저해효과는 각각 28.60 86.20\%와 36.53 97.07\%를 나타내 동일 농도 범위 내에서의 양성대조군 allopurinol의 저해효과 $89.67 \sim 97.33 \%$ 에 비해 유의하게 낮았다. 열수추출물 농도 8.0 $\mathrm{mg} / \mathrm{mL}$ 에서의 XO 저해효과는 allopurinol에 비해 조금 낮았으 나 통계적인 유의성은 없었다.

\section{Acetylcholinesterase (AChE) 저해 활성}

마른진휽버섯 자실체의 메탄올과 열수추출물의 $\mathrm{AChE}$ 효소 에 대한 저해활성은 추출물의 농도 $0.063 \sim 1.0 \mathrm{mg} / \mathrm{mL}$ 에서 수 행하여 그 결과를 Figure 3 에 표시하였다. 실험을 수행한 농도 범위에서 메탄올과 열수 추출물의 $\mathrm{AChE}$ 저해활성은 각각 $79.33 \sim 96.17 \%$ 와 59.67 89.33\%로 나타나 동일 농도 내에서 의 양성대조군 galathamine의 86.33 97.67\%에 비해 조금 낮 았다. 메탄올 추출물의 $\mathrm{AChE}$ 에 대한 저해 활성은 $0.25 ~ 1.0$ $\mathrm{mg} / \mathrm{mL}$ 의 농도에서 $93.73 \sim 96.17 \%$ 를 나타내 양성대조군 galanthamine의 94 96.67\%에 비해 조금 낮았으나 통계적인 유의성은 없었다. 


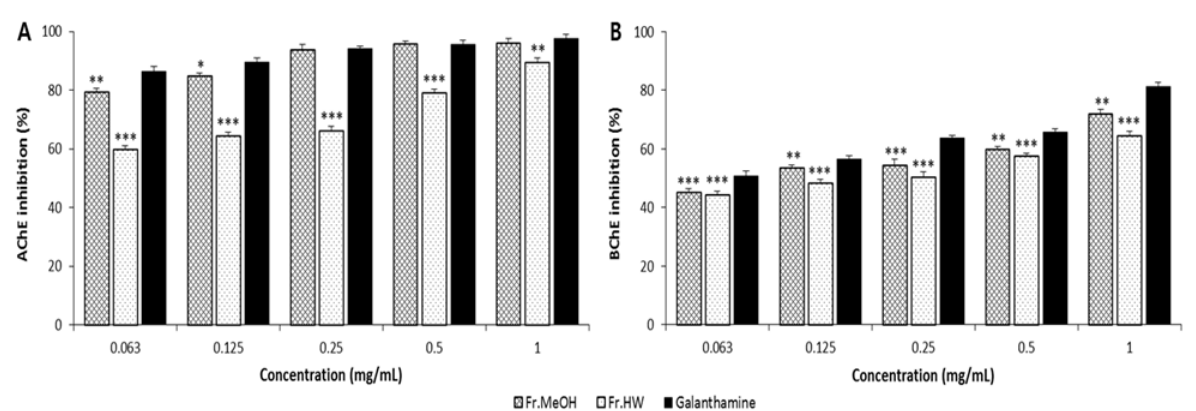

Figure 3. Cholinesterase inhibitory activity of methanol and hot water extracts from fruiting bodies of Phellinus gilvus. A, acetylcholinesterase inhibitory activity; B, butyrylcholinesterase inhibitory activity. The values are means \pm $\mathrm{SD}(\mathrm{N}=3) .{ }^{* \star} P \leq 0.001,{ }^{* \star} P \leq 0.01,{ }^{*} P \leq$ 0.05 vs. galanthamine group. Abbreviation: AChE, acetylcholinesterase; $\mathrm{BChE}$, butyrylcholinesterase; Fr.MeOH, fraction extracted with $80 \%$ methanol; Fr.HW, fraction extracted with hot water.

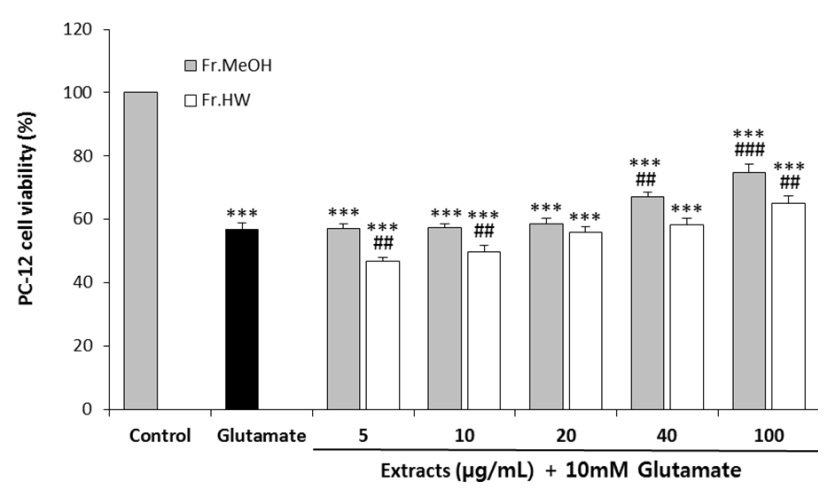

Figure 4. Inhibitory effect of methanol and hot water extracts from fruiting bodies of Phellinus gilvus on glutamate-induced cytotoxicity in $\mathrm{PC}-12$ cells. Values are means $\pm \mathrm{SD}(\mathrm{N}=3)$. ${ }^{\star \star \star} P \leq$ 0.001 vs. control group. ${ }^{\# \#} P \leq 0.001,{ }^{\#} P<0.01$ vs. glutamate group. Abbreviation: Fr.MeOH, fraction extracted with $80 \%$ methanol; Fr.HW, fraction extracted with hot water.

\section{Butyrylcholinesterase (BChE) 저해 활성}

마른진휽버섯 자실체의 메탄올과 열수추출물의 $\mathrm{BChE}$ 에 대 한 저해활성은 $0.063 \sim 1.0 \mathrm{mg} / \mathrm{mL}$ 의 농도에서 각각 45.17 $71.67 \%$ 와 44.10 64.33\%로 나타나 동일한 농도 범위에서의 양성대조군 galathamine의 저해효과 50.57 81.17\%에 비해 유의하게 낮았다(Figure 4). 마른진휽버섯 추출물의 $\mathrm{BChE}$ 에 대한 저해효과는 처리 농도가 증가함에 따라 농도 의존적으로 저해효과도 증가하는 경향을 나타냈다.

\section{Glutamate 독성에 의해 유도된 세포사멸의 억제효과}

PC-12 세포에 glutamate를 처리하여 유도된 독성이 마른진 흙버섯 자실체의 메탄올과 열수 추출물의 첨가에 의해 억제된 결과를 Figure 5에 표시하였다. RPMI-1640 배지에 glutamate 를 $10 \mathrm{mM}$ 농도로 첨가하여 PC-12 세포를 배양하고 생존율을 측정한 결과 $56.67 \%$ 를 나타내 glutamate 첨가 없이 배양한 대 조군의 PC-12 세포의 생존율 $100 \%$ 에 비해 유의하게 낮았다. Glutamate를 배지에 첨가하고 PC-12 세포를 12 시간 배양한

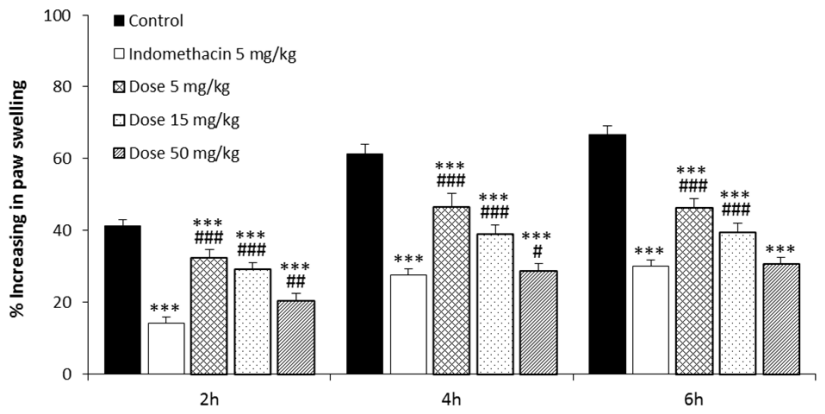

Figure 5. Inhibitory effect of methanol extract of fruiting bodies from Phellinus gilvus on carrageenan-induced paw edema in rats. The values are means $\pm \mathrm{SD}(\mathrm{N}=5)$. ${ }^{* \star *} P \leq 0.001$ vs. control group; ${ }^{\# \# \#} P \leq 0.001$, " $P<0.05$ vs. indomethacin group.

후 각각 $5,10,20,40,100 \mathrm{mg} / \mathrm{mL}$ 농도의 메탄올추출물을 첨 가하여 24시간 배양 후 측정한 세포의 생존율은 각각 $57.00 \%$, $57.17 \%, 58.33 \%, 67.00 \%, 74.77 \%$ 를 보였고, 열수 추출물을 첨 가해 동일 조건에서 배양한 세포의 생존율은 각각 $49.83 \%$, $56.33 \%, 58.10 \%, 65.17 \%$ 를 나타냈다. 따라서 glutamate가 첨 가된 RPMI-1640 배지에 메탄올 추출물 $(40 \mathrm{mg} / \mathrm{mL}$ 와 100 $\mathrm{mg} / \mathrm{mL})$ 과 열수 추출물 $(100 \mathrm{mg} / \mathrm{mL})$ 을 각각 첨가해 배양한 PC-12 세포의 생존율은 RPMI-1640 배지에 glutamate만을 첨가해 배양한 세포의 생존율 $56.67 \%$ 에 비해 통계적으로 유의 하게 높아 glutamate의 처리에 의해 PC-12 세포에 유도된 독 성이 마른진흙버섯 추출물의 처리에 의해 억제되는 효과를 나 타내는 것으로 사료된다.

\section{Nitric oxide (NO) 생성 저해 효과}

DMEM 배지에 RAW 264.7 세포를 배양하여 생성된 대조군 의 $\mathrm{NO}$ 농도는 $6.47 \mu \mathrm{M}$ 이었으나 DMEM 배지에 LPS를 1.0 $\mathrm{\mu g} / \mathrm{mL}$ 농도로 첨가하여 배양한 양성대조군의 RAW 264.7 세 포가 생성한 $\mathrm{NO}$ 는 $43.53 \mu \mathrm{M}$ 로 측정되었다. 배지에 메탄올 추 출물을 각각 $0.5 \mathrm{mg} / \mathrm{mL}, 1.0 \mathrm{mg} / \mathrm{mL}, 2.0 \mathrm{mg} / \mathrm{mL}$ 농도로 처리 하고 RAW 264.7 세포를 배양한 뒤 $1.0 \mathrm{mg} / \mathrm{mL}$ 의 LPS를 첨가하 

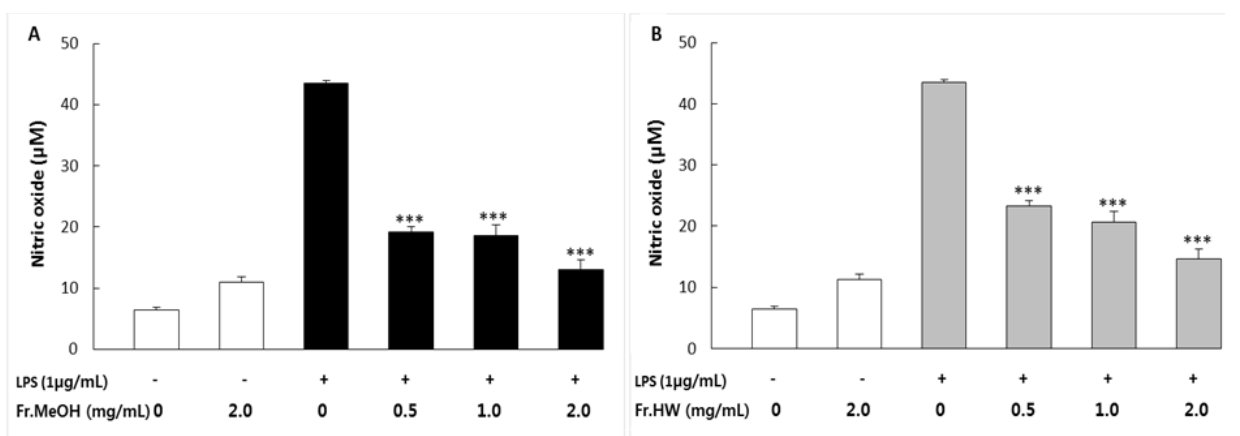

Figure 6. Inhibitory effect of methanol and hot-water extracts from fruiting bodies of Phellinus gilvus on LPSinduced nitric oxide production in RAW 264.7 cells. The cells were incubated for 24 hours with LPS $(1 \mu \mathrm{g} / \mathrm{mL})$ in the presence or absence of indicated concentration of mushroom extracts. The values are means $\pm S D$ $(\mathrm{N}=3) .{ }^{* * *} P \leq 0.001$ vs. LPS treated group. Abbreviation: Fr.MeOH, fraction extracted with $80 \%$ methanol; Fr.HW, fraction extracted with hot water.

여 배양한 RAW 264.7 세포가 생성한 $\mathrm{NO}$ 의 농도는 각각 19.17 $\mathrm{mM}, 18.67 \mathrm{mM}, 13.10 \mathrm{mM}$ 로 측정되었고, RAW 264.7 세포에 동일한 농도의 열수 추출물을 처리하여 생성된 $\mathrm{NO}$ 는 각각 $23.33 \mathrm{mM}, 20.67 \mathrm{mM}, 14.77 \mathrm{mM}$ 로 나타났으며, 각각의 농도 의 메탄올과 열수 추출물 처리에 의해 RAW 264.7 세포에 생성 된 NO는 양성대조군에 비해 모두 유의하게 낮았다(Figure 6).

\section{Carrageenan에 의한 부종유발 및 항염효과}

앞의 실험에서 RAW 264.7 세포에 LPS를 처리해 생성된 NO 의 생성 저해효과가 메탄올 추출물이 열수 추출물에 비해 높게 나타나 흰쥐 뒷발바닥의 부종 유발 억제실험은 메탄올 추출물 만을 이용해수행하였다. 부종을 유발하는 기염제인 carrageenan 만을 주사한 대조군의 흰쥐 뒷발에 생성된 부종(edema)의 용 적은 주사 후 2 6시간에 41.16 66.70\% 증가했고, 소염제인 indomethacin을 $5 \mathrm{mg} / \mathrm{kg}$ 농도로 투여 후 carrageenan을 주 사한 양성대조군의 부종 용적은 동일 시간대에 14.16 $30.10 \%$ 증가했다. 이에 반해 마른진휽버섯 메탄올 추출물을 5 $\mathrm{mg} / \mathrm{kg}$ 농도로 투여 후 carrageenan을 주사한 실험군의 부종 용적은 $32.40 ~ 46.80 \%$ 증가했으며, $15 \mathrm{mg} / \mathrm{kg}$ 의 메탄올 추출 물을 투여한 실험군의 부종용적은 $29.20 ~ 39.40 \%$ 증가했고, $50 \mathrm{mg} / \mathrm{kg}$ 농도의 메탄올 추출물을 투여한 실험군의 부종용적 의 증가율은 $20.40 ~ 30.60 \%$ 를 나타나서 투여한 메탄올 추출 물의 농도가 높아짐에 따라 농도 의존적으로 부종의 저해효과 도 증가하였다.

\section{고 찰}

폴리페놀과 플라보노이드 화합물은 생체 내에서 활성산소의 생성을 억제하거나 제거하여 세포와 조직의 손상을 방지하는 항산화 작용을 통해 생체를 보호하는 것으로 알려져 있다[27]. 일반적으로 식물에는 다량의 폴리페놀과 플라보노이드가 함유 되어 있으나 죽은 식물을 분해해 살아가는 버섯에는 소량 함유
되어 있다[28]. 마른진휽버섯 자실체에서 메탄올로 추출한 총 페놀과 총 플라보노이드 함량은 각각 $31.37 \mathrm{mg} / \mathrm{g}$ 과 $6.17 \mathrm{mg} / \mathrm{g}$ 으로 Yim 등[29]이 보고한 느타리 자실체의 메탄올 추출물의 페놀 함량 $5.1 \mathrm{mg} / \mathrm{g}$ 과 플라보노이드 함량 $0.1 \mathrm{mg} / \mathrm{g}$ 에 비해 높 은 것으로 나타났다. 따라서 마른진휽버섯 자실체에는 많은 양 의 페놀과 플라보노이드가 함유되어있어서 항산화작용을 비롯 한 여러 생리 활성의 효과를 높일 수 있을 것으로 사료된다.

통풍(gout)은 혈액 내에 요산(uric acid)이 과도하게 증가하 게 되면 용해성이 낮은 요산이 관절 부위에 바늘과 같은 결정체 의 형태로 침착되어 심한 통증을 일으키는 질병이다[30]. 체내 의 요산 생성은 퓨린(purine) 염기에 속하는 구아닌(guanine) 이 효소 작용에 의해 xanthine 또는 hypoxanthine으로 전환된 후 xanthine oxidase $(\mathrm{XO})$ 효소의 촉매 작용을 거쳐 생산된다. 혈액 내 요산의 $70 \%$ 정도는 체내의 대사과정을 통해 생성되고 약 $30 \%$ 는 음식물을 통해 섭취하기 때문에 체내의 과도한 요산 농도를 낮추기 위해서는 음식물을 가려서 섭취하기보다는 체내 의 요산 생성에 관여하는 XO 효소의 활성을 저해하는 것이 중요 하다[31]. 마른진흙버섯 자실체의 메탄올과 열수 추출물의 XO 에 대한 저해효과는 $0.5 \mathrm{mg} / \mathrm{mL}$ 농도에서 각각 $28.6 \%$ 와 $36.53 \%$ 로 나타나양성대조군 allopurinol의 $89.67 \%$ 에 비해 통 계적으로 유의하게 낮았으나 $(P \leq 0.001)$ 고농도인 $8.0 \mathrm{mg} / \mathrm{mL}$ 에서의 메탄올 추출물, 열수 추출물 그리고 allopurinol은 각각 $86.20 \%, 97.07 \%, 97.33 \%$ 의 저해효과를 나타내서 allopurinol 에 비해 열수 추출물의 저해효과가 유의하게 낮았으나 $(P \leq$ $0.01)$, 이 농도에서의 메탄올 추출물의 $\mathrm{XO}$ 에 대한 저해효과는 allopurinol과 비교가 될 만큼 높아 $\mathrm{XO}$ 를 억제할 수 있는 건강 식품으로 충분한 효과를 갖고 있다고 사료된다. 또한 메탄올과 열수 추출물의 $\mathrm{XO}$ 에 대한 저해효과는 농도가 높아짐에 따라 농 도 의존적으로 증가하는 경향을 보였다. Costantino 등[32]은 항산화 효과가 높아 다이어트에 이용되는 까치밥나무속에 속하 는 Ribes rubrum과 Ribes nigram의 열매에서 분리한 페놀과 플라보노이드 성분이 $\mathrm{XO}$ 에 대한 높은 저해효과를 갖고 있어서 
건강식품으로도 이용이 가능하다고 보고하였다. Alam 등[33] 은 아위버섯(Pleurotus ferulae)의 자실체에서 열수로 추출한 물질의 XO에 대한 저해효과가 $0.5 \sim 8.0 \mathrm{mg} / \mathrm{mL}$ 의 농도에서 $3.21 \sim 5.56 \%$ 로 보고하였는데 이는 마른진훍버섯 자실체의 메탄올과 열수추출물의 XO에 대한 저해효과가 동일 농도범위 내에서 아위버섯 추출물에 비해 높게 나타난 것으로 마른진흙 버섯의 자실체에 함유된 페놀과 플라보노이드 함량이 느타리에 비해 상대적으로 높은 것에 기인한다고 사료된다.

치매와 알츠하이머의 가장 큰 특징의 하나는 기억력이 크게 감퇴하여 인간의 삶이 황폐화 되는 병으로 뇌의 신경전달 물질 인 $\mathrm{ACh}$ 나 BCh 등이 $\mathrm{AChE}$ 나 BChE 등의 효소에 의해 과도하게 분해되어 뇌에 $\mathrm{ACh}$ 나 $\mathrm{BCh}$ 등 콜린(choline)의 함량이 부족해 져서 일어나는 현상이다. 따라서 감퇴한 기억력을 높이기 위해 서는 $\mathrm{AChE}$ 나 $\mathrm{BChE}$ 효소의 작용을 억제해 $\mathrm{ACh}$ 나 $\mathrm{BCh}$ 를 과도 하게 분해되는 것을 억제하는 donepezil, rivastigmine, galanthamine 등과 같은 cholinesterase 저해제가 사용되고 있다[34]. 마른진흙버섯자실체의 메탄올 추출물은 $0.063 \mathrm{mg} / \mathrm{mL}$ 와 $1.0 \mathrm{mg} / \mathrm{mL}$ 농도에서 $\mathrm{AChE}$ 에 대한 저해활성이 각각 $79.33 \%$ 와 $96.17 \%$ 로 나타났고 동일 농도에서 열수 추출물은 각각 $59.67 \%$ 와 $89.33 \%$ 의 저해활성을 나타내 양성대조군인 galathamine의 저해활성 $86.33 \%$ 와 $97.67 \%$ 에 비해 통계적으 로 유의하게 낮았다. 동일 농도에서 $\mathrm{BChE}$ 에 대한 메탄올 추출 물의 저해활성은 각각 $45.17 \%$ 와 $71.67 \%$ 를 나타냈고, 열수 추 출물은 각각 $44.10 \%$ 와 $64.33 \%$ 의 저해효과를 보여 galanthamine 의 $50.57 \%$ 와 $81.17 \%$ 에 비해 유의하게 낮았다. 또한 메탄올 추 출물의 $\mathrm{AChE}$ 와 $\mathrm{BChE}$ 에 대한 저해활성은 모든 농도범위에서 열수 추출물에 비해 높았다. Nguyen 등[35] 등은 기와층버섯의 자실체메탄올추출물의 $\mathrm{AChE}$ 에 대해 $0.063 \mathrm{mg} / \mathrm{mL}$ 와 1.0 $\mathrm{mg} / \mathrm{mL}$ 에서 각각 $64.19 \%$ 와 $83.34 \%$ 의 저해활성을 나타냈으 며, 동일 농도에서 열수추출물은 각각 $51.44 \%$ 와 $77.53 \%$ 의 저 해효과를 보였다고 하였다. Yoon과 Lee[36]는 장미무당버섯 자실체의 메탄올 추출물은 $0.063 \mathrm{mg} / \mathrm{mL}$ 과 $1.0 \mathrm{mg} / \mathrm{mL}$ 의 농도 에서 $\mathrm{AChE}$ 에 대한 저해활성이 각각 $45.67 \%$ 와 $75.57 \%$ 를 나타 냈으며, 동일 농도에서 열수 추출물은 각각 $33.66 \%$ 과 $74.08 \%$ 의 저해효과를 나타냈다고 보고하였다. 마른진흙버섯 자실체 의 메탄올과 열수 추출물의 $\mathrm{AChE}$ 와 $\mathrm{BChE}$ 에 대한 저해효과는 앞의 기와층버섯과 장미무당버섯에 비해 높은 것으로 나타났 다. 따라서 마른진휽버섯 자실체 추출물의 $\mathrm{AChE}$ 나 BChE에 대 한 강한 저해효과를 효율적으로 이용하기 위해서는 앞으로 유 효성분을 중심으로 Alzheimer병과 같은 뇌의 퇴행성 질환에 관 한 추가 연구가 필요할 것으로 사료된다.
Glutamate는 중추신경계의 신경 흥분성 전달물질이나 뇌에 필요이상으로 과다하게 존재하게 되면 신경세포에 독성을 나타 낸다고 보고되어 있다[37]. 뇌 속에 glutamate가 과도하게 축적 되면 뇌세포 내에 활성산소(reactive oxygen species)가 다량 으로 생성되면서 뇌신경 세포벽의 지방질 산화가 촉진되어 뇌 신경 세포의 사멸이 유도되면서 신경세포의 손상이 일어나 $\mathrm{AD}$ 와 같은 신경 퇴행성 질환이 발생할 가능성이 높아진다[38, 39]. 본 실험에서 $10 \mathrm{mM}$ 의 glutamate가 함유된 배지에 PC-12 세 포를 배양하고 각각 농도가 다른 마른진흙버섯 자실체의 메탄 올 추출물을 첨가하고 배양하여 세포의 생존율을 측정한 결과 $40 \mathrm{mg} / \mathrm{mL}$ 와 $100 \mathrm{mg} / \mathrm{mL}$ 를 첨가한 실험군이 $10 \mathrm{mg} / \mathrm{mL}$ 의 glutamate만을 첨가해 배양한 대조군에 비해 유의하게 세포의 생존율이 높았으며 $(P \leq 0.01)$, 열수 추출물의 경우에는 100 $\mathrm{mg} / \mathrm{mL}$ 농도 처리 군에서만 glutamate만 처리한 군에 비해 생 존율이 유의하게 높았다 $(P \leq 0.01)$. Choi 등[40]은 $20 \mathrm{mg} / \mathrm{mL}$ 농도의 glutamate를 PC-12 세포 배양액에 첨가하여 독성을 유 발한 후 느릅나무 근피의 에틸아세테이트와 부탄올 분획을 처 리하여 배양한 결과 glutamate만을 처리하여 배양한 실험 군에 비해 세포의 생존율이 유의하게 높았다고 보고하였는데 이는 PC-12 세포 내에 glutamate에 의해 생성된 활성산소의 독성이 느릅나무 추출물의 항산화 작용에 의해 감소되어 PC-12 세포 의 생존율이 높아지게 된 것이라고 하였다. 따라서 본 실험에서 마른진흙버섯 자실체의 메탄올과 열수추출물에 의해 glutamate 가 처리된 PC- 12 세포의 생존율이 증가된 것은 이 버섯의 자실 체에 함유된 풍부한 페놀과 플라보노이드 등의 항산화 성분이 glutamate가 PC-12 세포에 유도한 활성산소의 독성을 감소시 킨 때문으로 사료된다.

Lipopolysaccharide (LPS)는 그람 음성 세균의 세포막 구조 성분으로 다당류, 인지질 및 소량의 단백질로 구성되어 있으며 생체 내의 대식세포(macrophage)를 자극하여 inducible nitric oxide synthase (iNOS)를 발현시켜 L-arginine으로부터 nitric oxide $(\mathrm{NO})$ 를 생성해 매개성 면역반응을 일으킨다고 알 려져 있다[41]. LPS는 또한 대식세포를 자극하여 tumor necrosis factor- $\alpha$ (TNF- $\alpha$ ), interleukin-6 (IL-6), interleukin-1 $\beta$ (IL-1 $\beta$ ) 등과 같은 염증 촉진성 사이토카인(cytokine)의 생산을 증가시키는 것으로 보고되었다[42, 43]. 본 실험에서 DMEM 배 지에 LPS를 첨가해 배양한 양성대조군의 RAW 264.7 세포가 생 성한 $\mathrm{NO}$ 의 농도는 $43.53 \mathrm{mM}$ 로 DMEM 배지에 RAW 264.7 세 포만을 배양해 생성된 대조군의 $\mathrm{NO}$ 의 농도 $6.47 \mu \mathrm{M}$ 에 비해 6.73 배 증가하였다. 메탄올 추출물을 $2.0 \mathrm{mg} / \mathrm{mL}$ 농도로 배지 에 처리하고 RAW 264.7 세포를 배양하여 생산된 실험 군의 
$\mathrm{NO}$ 농도는 $13.10 \mu \mathrm{M}$ 로 양성대조군에 비해 3.33배 감소하였고 $2.0 \mathrm{mg} / \mathrm{mL}$ 농도의 열수 추출물을 첨가하여 배양한 RAW 264.7 세포가 생성한 $\mathrm{NO}$ 의 농도는 $14.77 \mathrm{mM}$ 로 측정되어 2.95 배 감소하였다. 메탄올과 열수 추출물은 모든 실험 농도의 범위에서 RAW 264.7 세포의 $\mathrm{NO}$ 의 생성을 저해하였으며 메탄 올 추출물이 열수 추출물에 비해 $\mathrm{NO}$ 의 생성 저해효과가 높았 다. Jang 등[44]은 낙엽송충버섯(Phellinus pini) 자실체의 메 탄올 추출물의 hexane 분획을 RAW 264.7 세포 배양액에 첨가 하고 LPS를 처리하여 생성된 NO가 LPS만을 처리한 양성대조 군에 비해 농도 의존적으로 유의하게 감소하였는데 이는 hexane 분획에 함유된 2종의 ergosterol 유도체에 의해 나타난 저해효과라고 보고하였다. Fangkrathok 등[45]은 Lentinus polychrous의 균사체 추출물이 NO의 생성에 관여하는 RAW 264.7 대식세포 내의 iNOS 효소의 발현을 저해하여 RAW 264.7 세포에서 생성되는 NO가 감소하는 것을 확인하였고 추 출물에 농도 의존적으로 $\mathrm{NO}$ 의 생성이 감소했다고 보고하였다. 본 실험에서도 RAW 264.7 세포에 처리한 마른진흙버섯 메탄 올과 열수추출물의 농도가 높아짐에 따라 $\mathrm{NO}$ 의 생성량도 농도 의존적으로 유의성 있게 감소되는 것이 관찰되었다.

부종(edema)은 신체 내의 조직과 장기 주변 공간에 체액이 저류되어 붓는 상태를 말하며, 신체 부위의 어느 곳이나 생길 수 있다. 다리나 손에 부종이 있는 경우 말초 부종이라고 하고, 복 부에 물이 차는 경우 복수, 폐에 물이 차는 경우 폐부종이라 부른 다[46]. Carrageenan은 홍조류의 일종인 Chondrus crispus에 서 추출한 점액성의 유황이 풍부한 다당류로 동물에 염증을 효 과적으로 유발하는 물질이다. Carrageenan에 의한 초기의 염 증반응은 histamine, kinins, serotonin, prostaglandin E 등에 의해 혈관의 확장이나 투과성이 증가하고 이후에는 bradykinin 에 의해 부종을 수반하는 지속적인 염증반응이 일어나는 것으 로 보고되어 있다[47]. Carrageenan을 흰쥐의 뒷발 바닥에 주 사하여 급성 부종을 유발하는 실험은 소염 물질의 염증 저해 효 과를 확인하는 체내검사(in vivo) 모델로 널리 알려져 있다[48]. 마른진휽버섯의 메탄올추출물은 실험에 사용한 모든 농도에서 부종을 저해하는 효과가 나타났으나 $50 \mathrm{mg} / \mathrm{kg}$ 을 투여한 실험 군은 $5.0 \mathrm{mg} / \mathrm{kg}$ 을 투여한 실험 군에 비해 투여 6시간 경과 후의 부종 저해율은 2.18 배로 나타나 고농도 추출물을 투여한 실험 군의 저해효과가 저농도 투여 군에 비해 크게 높았다. 그러나 $5.0 \mathrm{mg} / \mathrm{kg}$ 의 동일 농도 범위에서 메탄올 추출물의 저해효과는 양성대조군인 indomethacin에 비해 유의하게 낮았다. $\operatorname{Lim}$ 등 [49]은 carrageenan으로 부종을 유발한 흰쥐에 목질진휽버섯 (Phellinus linteus)의 자실체 열수추출물을 투여하여 항염증
효과를 측정한 결과 투여한 추출물 농도가 증가함에 따라 부종 저해효과도 비례해서 증가했다고 보고하였으며 본 실험에서도 추출물의 농도 증가에 따라 부종의 저해효과도 높아지는 것이 관찰되었다. 따라서 마른진훍버섯 자실체에 는 흰쥐의 부종을 현저하게 저해하는 물질이 함유되어 있을 것으로 추정되며, 본 실험의 중요성과는 우리나라의 민간이나 한방에서 오랫동안 약 용으로 사용해왔던 마른진휽버섯을 실험을 통해 통풍, 치매 및 염증의 치료에 이용이 가능하다는 것을 입증한 것이 가장 중요 하다고 판단된다. 그러므로 이들 추출물의 분획을 통한 유효성 분의 규명과 이를 이용한 여러 염증질환을 대상으로 추가의 실 험이 필요할 것으로 사료된다.

\section{요 약}

본 연구에서는 마른진휽버섯 자실체를 메탄올과 열수를 이 용해추출한물질의 anti-xanthine oxidase, anti-cholinesterase 및 염증 저해 효과에 대한 연구를 수행하였다. 마른진흙버섯 자 실체의 메탄올 추출물과 열수 추출물의 xanthine oxidase에 대 한 저해효과는 양성대조군으로 사용한 allopurinol과 대등하게 높은 효과를 나타냈다. Acetylcholinesterase에 대한 메탄올 추 출물의 $1.0 \sim 2.0 \mathrm{mg} / \mathrm{mL}$ 농도에서의 저해활성은 양성대조군인 galanthamine과 유사하게 높았지만 butyrylcholinesterase에 대한 메탄올과 열수 추출물의 저해활성은 양성대조군에 비해 실험에 사용한 모든 농도범위에서 유의하게 낮았다. PC-12 세 포에 glutamate의 처리에 의해 유도된 독성은 $40 \mathrm{mg} / \mathrm{mL}$ 와 $100 \mathrm{mg} / \mathrm{mL}$ 농도의 메탄올 추출물과 $100 \mathrm{mg} / \mathrm{mL}$ 농도의 열수 추출물의 처리에 의해 크게 완화되어 PC- 12 세포의 생존율이 유의하게 증가하는 것이 관찰되었다. 마른진휽버섯의 메탄올 과 열수 추출물의 염증 저해 실험에서 RAW 264.7 대식세포에 메탄올 추출물을 $2.0 \mathrm{mg} / \mathrm{mL}$ 농도로 처리하고 염증을 매개하는 LPS를 추가로 투여한 후 RAW 264.7 세포에 생성되는 NO를 측 정한 결과, 양성대조군에 비해 3.37 배 높은 저해효과를 나타냈 고, 처리한 자실체 메탄올 추출물의 농도가 증가함에 따라 생성 된 $\mathrm{NO}$ 의 양이 현저하게 감소하는 경향을 나타내었다. 또한 기 염제인 carrageenan에 의해 흰쥐 뒷발에 유도된 부종 저해 실 험에서는 투여한 버섯 추출물의 농도가 증가함에 따라 흰쥐의 뒷발에 유도된 부종의 용적이 농도 의존적으로 감소하는 경향 을 나타냈다. 따라서 마른진휽버섯 자실체에 함유된 물질은 acetylcholinesterase과 butyrylcholinesterase 등의 cholinesterase에 대한 저해작용과 glutamate에 의해 유도된 PC-12세 포의 독성을 완화하고 또한 염증을 저해하는 효과를 나타내 기 
억력이 감퇴되는 초기 알츠하이머병과 염증을 완화하는 천연 소염제로의 이용이 가능할 것으로 사료된다.

\section{Acknowledgements: None \\ Conflict of interest: None}

\section{REFERENCES}

1. Francis PT, Palmer AM, Snape M, Wilcock GK. The cholinergic hypothesis of alzheimer's disease: a review of progress. J Neurol Neurosurg Psychiatry. 1999;66:137-147.

2. Beal F. Aging, energy and oxidative stress in neurodegenerative diseases. Ann Neurol. 1995;38:357-366.

3. Coyle JT, Price DL, DeLong MR. Alzheimer's disease: a disorder of cholinergeric innervation. Science. 1983;219:1184-1190.

4. Talesa VN. Acetylcholinesterase in Alzheimer's disease. Mech Aging Dev. 2001;122:1961-1969.

5. Block F, Pergande G, Schwarz M. Flupirtine reduces functional deficits and neuronal damage after global ischemia in rats. Brain Res. 1997;754:279-284.

6. Colovic MB, Krstic DZ, Lazarevic-Pasti TD, Bondzic AM, Vasic VM. Acetylcholinesterase inhibitors: pharmacology and toxicology. Curr Neuropharmacol. 2013;11:315-335.

7. Xie QW, Whisnant R, Nathan C. Promoter of the mouse gene encoding calcium-independent nitric oxide synthase confers inducibility by interferon $\gamma$ and bacterial lipopolysaccharide. J Exper Medi. 1993;177:1779-1784.

8. Medzhitov R. Origin and physiological roles of inflammation. Nature. 2008:454:428-435.

9. MacMicking J, Xie QW, Nathan C. Nitric oxide and macrophage function. Annu Rev Immunol. 1997;15:323-350.

10. Hippeli S, Elstner EF. Inhibition of biochemical model reactions for inflammatory processes by plant extracts: a review on recent developments. Free Radi Res. 1999;31(Suppl):S81-S87.

11. Boumpas DT, Chrousos GP, Wilder RL, Cupps TR, Balow JE. Glucocorticoid therapy of immune-mediated diseases:basic and clinical correlates. Ann Intern Med. 1993;119:1198-1208.

12. Wasser SP, Weis AL. Therapeutic effects of substances occurring in higher Basidiomycetes mushrooms: a modern perspective. Crit Rev Immunol. 1999;19:65-96.

13. Lindequist U, Niedermeyer THJ, Julich WD. The pharmacological potential of mushrooms. eCAM. 2005;2:285-299.

14. Yoon KN, Jang HS, Jin GH. Antioxidant, anti-diabetic, anti-cholinesterase, and nitric oxide inhibitory activities of fruiting bodies of Agaricus brasiliensis. Korean J Clin Lab Sci. 2015; 47:194-202.

15. Park WH, Lee HD. Illustrated book of Korean medicinal mushrooms. 2nd ed. Seoul: Kyohak Publishing; 2003. p359360.

16. Bae JS, Jang KH, Yim H, Jin HK. Polysaccharide isolated from Phellinus gilvus inhibit melanoma growth in mouse. Caner Lett. 2005;218:43-52.

17. Yoon KN, Jang HS. Antioxidant and antimicrobial activities of fruiting bodies of Phellinus gilvus collected in Korea. Korean J
Clin Lab Sci. 2016;48:355-364.

18. Shim SM, Im KH, Kim JW, Shim MJ, Lee MW, Lee TS. Studies on immuno-modulatory and antitumor effects of crude polysaccharides extracted from Paecilomyces sinclairii. Korean J Mycol. 2003;31:155-160.

19. Swain T, Hillis WE, Ortga M. Phenolic constituents of Prunus domestica. I. Quantitative analysis of phenolic constituents. J Sci Food Agric. 1959;10:83-88.

20. Moreno MIN, Isla MI, Sampietro AR, Vattuone MA. Comparison of the free radical scavenging activity of propolis from several region of Argentina. J Enthnopharmcol. 2000;71:109-114.

21. Mosmann T. Rapid colorimetric assay for cellular growth and survival: application to proliferation and cytotoxicity assays. Immunol Meth. 1983;65:55-63.

22. Stirpe F, Corte Della E. The regulation of rat liver xanthine oxidase. Conversion in vitro of the enzyme activity from dehydrogenase (type D) to oxidase (type O). J Biol Chem. 1969;244:3855-3863.

23. Ellman GL, Courtney KD, Andres V Jr, Featherstone RM. A new and rapid colorimetric determination of acetylcholinesterase activity. Biochem Pharmacol. 1961;7:88-95.

24. Greene LA, Tischler AS. Establishment of a noradrenergic clonal line of rat adrenal pheochromocytoma cells which respond to nerve growth factor. Proc Natl Acad Sci. 1976;73:2424-2428.

25. Ma S, Liu H, Jiao H, Wang L, Chen L, Liang J, et al. Neuroprotective effect of ginkgolide K on glutamate-induced cytotoxicity in PC 12 cells via inhibition of ROS generation and $\mathrm{Ca}^{2+}$ influx. Neurotoxicol. 2012;33:59-69.

26. Ryu JH, Ahn H, Kim JY, Kim YK. Inhibitory activity of plant extracts on nitric oxide synthesis in LPS-activated macrophage. Phytother Res. 2003;17:485-489.

27. Winter CA, Risley EA, Nuss GW. Carrageenan induced edema in the hind paw of rat as an assay for anti-inflammatory activity. Proc Soc Exp Biol Med. 1962;111:544-547.

28. Rocha-Guzmn NE, Gonzlez-Laredo JA, Conzalez-Laredo RF, Reynoso-Camacho R, Ramos-Gmez M, Garcia-Gasca T, et al. Antioxidant activity and genotoxic effect on HeLa cells of phenolic compounds from infusions of Quercus resinosa leaves. Food Chem. 2009;115:1320-1325.

29. Yim HS, Chye FY, Ho SK, Ho WC. Phenolic profiles of selected edible wild mushrooms as affected by extraction solvent, time and temperature. Asian J Food Ag-Ind. 2009;2:392-401.

30. Ling X, Bochu W. A review of phytotherapy of gout: perspective of new pharmacological treatments. Pharmazie. 2014;69:243-256.

31. Storch I, Ferber E. Detergent-amplified chemiluminescence of lucigenin for determination of superoxide amino production by NADPH oxidase and xanthine oxidase. Anal Biochem. 1988; 169:262-267.

32. Costantino L, Albasini A, Rastelli G, Benvenuti S. Activity of polyphenolic crude extracts as scavengers of superoxide radicals and inhibitors of xanthine oxidase. Planta Med. 1992;58: 342-344.

33. Alam N, Yoon KN, Lee JS, Cho HJ, Lee TS. Consequence of the antioxidant activities and tyrosinase inhibitory effects of various extracts from the fruiting bodies of Pleurotus ferulae. Saudi J Biol Sci. 2012;19:111-118. 
34. Tayebati SK, Di Tullio MA, Amenta F. Effect of treatment with the cholinesterase inhibitor rivastigmine on vesicular acetylcholine transporter and choline acetyltransferase in rat brain. Clin Exp Hypertens. 2004;26:363-373.

35. Nguyen TK, Shin DB, Lee KR, Shin PG, Cheong JC, Yoo YB, et al. Antioxidant, anti-inflammatory and anti-acetylcholinesterase activities of fruiting bodies of Phellinus xeranticus. J Mushroom Sci Prod. 2013;11:278-286.

36. Yoon KN, Lee TS. In vitro antioxidant, anti-hyperglycemic, anti-cholinesterase, and inhibition of nitric oxide production activities of methanol and hot water extracts of Russula rosacea mushroom. J Mushrooms. 2015;13:1-10.

37. Choi DW. Excitotoxic cell death. J Neurologic. 1991;23: 1262-1276.

38. Naito M, Umegaki H, Iguchi A. Protective effects of probucol against glutamate-induced cytotoxicity in neuronal cell line PC 12. Neurosci Lett. 1995;186:211-213.

39. Beal MF. Mechanisms of excitotoxicity in neurologic diseases. PASEB J. 1992;6: 3338-3344.

40. Choi WH, Oh YS, Ahn JY, Kim SR, Ha TY. Antioxidative and protective effects of UImus davidiana var. japonicus extracts on glutamate-induced cytotoxicity in PC 12 cells. Korean J Food Sci Technol. 2005;37:479-483.

41. Abbas AK, Lichtman AH, et al. Celluar and molecular immunology. 6th ed. Philadelphia: Saunders Elsevier; 2006. p75-77.
42. Nathan C. Nitric oxide as a secretory product of mammalian cell. The FASEB J. 1992;6:3051-3064.

43. Willeaume V, Kruys V, Mijatovic T, Huez G. Tumor necrosis factor-alpha production induced by viruses and by lipopolysaccharides in macrophages: similarities and differences. J Inflamm. 1996;46:1-12.

44. Jang HJ, Kim AK, Pyo MY. Yang KS. Inhibitors ofnnitric oxide syntheasis from Phellinus pini in murine macrophages. J Pharm Soc Korea. 2007;51:430-434.

45. Fangkrathok N, Junlatat J, Sripanidkulchai B. In vivo and in vitro anti-inflammatory activity of Lentinus polychrous extract. J Ethnopharm. 2013;147:631-637.

46. Lee IG. Differential diagnosis and treatment of generalized edema. J Korean Acad Fam Med. 2003;24:6-10.

47. Cho YS, Kim ND, Kim SA. Effects of concurrent administration of aspirin and prednisolone on the anti-inflammatory and antipyretic activities in rats. J Pharm Soc Korea. 1978;22:128-137.

48. Seibert K, Zhang Y, Leahy K, Hauser S, Masferrer J, Perkins W, Lee L, Isakson P. Pharmacological and biochemical demonstration of the role of cyclooxygenase 2 in inflammation and pain. Proc Natl Acad Sci USA. 1994;91:12013-12017.

49. Lim JH, Kim SH, Park NH, Moon CG, Kang, SS, Kim SH, Shin DH, Kim JC. Acute and chronic antiinflammatory effects of Phellinus linteus water extract in rats. J Biomed Res. 2010; 11:27-35. 